AL IBTIDA: JURNAL PENDIDIKAN GURU MI (2018) Vol 5 (1) : 83-94

DOI: http://dx.doi.org/ 10.24235/al.ibtida.snj.v5i1.2641

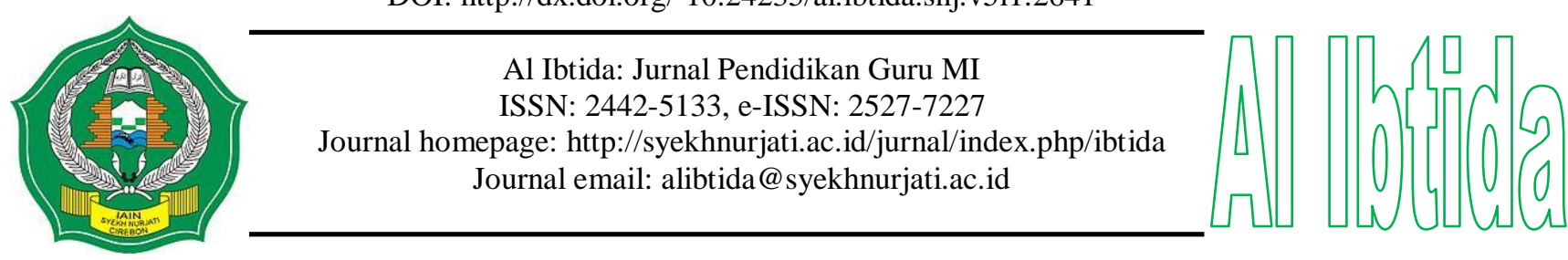

\title{
Pengaruh Model Cooperative Learning Tipe Think Pair Share (TPS) Terhadap Hasil Belajar Siswa pada Pelajaran Bahasa Arab di MI
}

\author{
Latifah* \\ *Program Studi Pendidikan Guru Madrasah Ibtidaiyah, Fakultas Ilmu Tarbiyah dan Keguruan, \\ IAIN Syekh Nurjati Cirebon \\ Email: latifa252@yahoo.co.id \\ Nur Aviya** \\ **Program Studi Pendidikan Guru Madrasah Ibtidaiyah, Fakultas Ilmu Tarbiyah dan Keguruan, \\ IAIN Syekh Nurjati Cirebon \\ Email: nur_aviya@yahoo.co.id
}

Received 08 April 2018; Received in revised form: 28 May 2018; Accepted 29 May 2018

Publish Online: 28 June 2018

\begin{abstract}
Abstrak
Pelajaran bahasa Arab merupakan salah satu mata pelajaran yang dirasakan sulit oleh siswa Madrasah Ibtidaiyah. Kesulitan tersebut dikarenakan dalam mempelajari bahasa arab dibutuhkan kejelian dalam memahaminya. Hal ini ditambah dengan kurangnya guru dalam menggunakan metode yang tepat dalam mengajarkan bahasa Arab. Penelitian ini bertujuan untuk mengetahui apakah penggunaan model cooperative learning tipe think pair share berpengaruh terhadap hasil belajar siswa pada pelajaran bahasa Arab di MIN Kota Cirebon. Penelitian ini merupakan penelitian kuantitatif yang menggunakan PretestPosttest Control Group Design dengan teknik pengumpulan data berupa tes, angket, dan dokumentasi. Sementara itu, teknik analisis data yang digunakan adalah analisis data angket, uji n-gain dan uji regresi. Hasil penelitian ini menunjukkan bahwa respon siswa terhadap penggunaan model cooperative learning tipe think pair share adalah sangat positif, yakni sebesar 80,4\%. Sementara itu, hasil belajar siswa kelas eksperimen mengalami peningkatan yang signifikan yakni sebesar 0,588 (dalam kategori sedang), dimana nilai rata-rata pretes sebesar 46 dan nilai rata-rata postes sebesar 78. Sedangkan penggunaan model cooperative learning tipe think pair share berpengaruh terhadap hasil belajar siswa pada mata pelajaran bahasa arab materi qiroh'ah di kelas V MI Negeri Kota Cirebon.
\end{abstract}

Kata kunci: think pair share, hasil belajar bahasa arab

\begin{abstract}
Arabic learning is one of the subjects that is difficult for students of Madrasah Ibtidaiyah. The difficulty is because in learning Arabic it takes a carefulness in understanding it. This is coupled with the lack of teachers in using the right method of teaching Arabic. This study aims to determine whether the use of cooperative learning type think pair share effect on student learning outcomes on learning Arabic in MIN Cirebon City. This
\end{abstract}


research is a quantitative research using Pretest-Posttest Control Group Design with data collection techniques such as test, questionnaire, and documentation. Meanwhile, the data analysis techniques used are questionnaire data analysis, n-gain test and regression test. The results of this study showed that students' responses to the use of cooperative learning model type think pair share is very positive, that is equal to $80.4 \%$. Meanwhile, the learning result of the experimental class students experienced a significant increase of 0.588 (in the medium category), where the average pretest value was 46 and the average value of postes was 78 . While the use of cooperative learning type think pair share influence on the results student learning on Arabic subject matter of qiroh'ah in class $\mathrm{V}$ MIN of Cirebon City.

Keywords: think pair share, arabic learning outcomes

\section{PENDAHULUAN}

Saat ini Bahasa Arab memiliki kedudukan yang sangat istimewa. Keistimewaan tersebut karena di samping sebagai bahasa al-Qur'an, bahasa Arab saat ini sudah menjadi bahasa Internasional. Menurut (Muharamsyah, Hardhienata, \& Entang, 2016) mengemukakan bahwa ada 29 negara yang menjadikan bahasa arab sebagai bahasa resmi negaranya. Selain itu, ada sekitar 2 milyar umat manusia (Umat Islam) yang kesehariannya tidak dapat lepas dari penggunaan bahasa arab, khususnya dalam menjalankan ritual/ibadah kepada Allah Swt. Oleh karena itu, mempelajari bahasa Arab menjadi penting dalam rangka menunjang berkomunikasi di kancah internasional maupun kesempurnaan ibadah kepada Allah swt.

Pelajaran bahasa Arab merupakan salah satu mata pelajaran yang diajarkan di Madrasah Ibtidaiyah. Pelajaran ini merupakan salah satu pelajaran yang dirasakan sulit oleh siswa. Karena dalam mempelajari bahasa arab dibutuhkan kejelian dalam memahaminya. Hal ini ditambah dengan kurangnya guru dalam menggunakan metode yang tepat dalam mengajarkan bahasa Arab. Berdasarkan penelitian yang dilakukan oleh (Masrifah, 2010) dan (Azizah, 2010) mengemukakan bahwa guru masih menggunakan metode yang monoton dan tidak menarik, seperti metode ceramah. Sehingga siswa merasa jenuh dan bosan serta tidak termotivasi dalam belajar bahasa arab.

Berdasarkan hasil observasi yang peneliti lakukan di MI Negeri Kota Cirebon, peneliti menemukan beberapa kendala yang dihadapi dalam proses pelajaran bahasa Arab. Salah satunya adalah kurangnya pemahaman siswa terhadap materi-materi yang diajarkan oleh guru. Kondisi tersebut disebabkan oleh berbagai hal, diantaranya guru masih menggunakan metode konvensional dalam menyampaikan materi pelajaran, sehingga siswa merasa bosan dan jenuh mengikuti pelajaran bahasa arab. Selain itu siswa juga tidak menyukai bahasa Arab karena menganggap bahwa bahasa Arab adalah mata pelajaran yang sulit dimengerti dan dipahami. Hal ini juga diperkuat dengan hasil wawancara peneliti dengan Bapak Oma selaku guru mata pelajaran bahasa Arab yang menyatakan bahwa masih banyak anak yang kurang minat dalam 
belajar bahasa Arab, sehingga dalam penguasaan dan pemahaman siswa terhadap materi bahasa Arab ketika belajar masih kurang dan belum maksimal.

Hal ini jika dibiarkan terus menerus akan mengakibatkan tidak tercapainya tujuan pelajaran seperti yang diharapkan. Mencermati hal tersebut, jelas sekali terdapat kesenjangan antara harapan dan kenyataan. Guru dituntut untuk mengubah praktik pelajaran di dalam kelas, dari yang bersifat teacher centre menjadi student centre. Menurut (Slavin, 2008) mengemukakan bahwa pembelajaran yang baik adalah pembelajaran yang tidak hanya dari guru, tetapi siswa ikut berperan aktif dalam kegiatan pelajaran. Selain itu, proses pelajaran juga harus berjalan dengan efektif. Agar proses pelajaran dapat berjalan dengan efektif, guru harus mampu meningkatkan kesempatan belajar bagi siswa, baik secara kualitas maupun kuantitas (Akhyak, 2005). Kesempatan belajar siswa dapat ditingkatkan dengan cara melibatkan siswa secara aktif dalam proses pembelajaran. Selanjutnya, guru juga harus mampu menunjukkan keseriusan saat mengajar agat dapat membangkitkan minat serta motivasi siswa untuk belajar. Makin banyak siswa yang terlibat aktif dalam proses pembelajaran, makin tinggi kemungkinan hasil belajar yang dicapainya. Sedangkan dalam meningkatkan kualitas dalam mengajar hendaknya guru mampu merencanakan program pengajaran dan melakukan dalam bentuk interaksi belajar mengajar.

Salah satu metode yang memungkinkan siswa terlibat aktif dalam proses pembelajaran adalah dengan menggunakan pembelajaran kooperatif (cooperative learning) tipe Think Pair Share (TPS). Pembelajaran kooperatif menurut (Sumantri, 2015) adalah rangkaian kegiatan belajar yang dilakukan oleh siswa dalam kelompok-kelompok tertentu untuk mencapai tujuan pembelajaran yang telah dirumuskan. Sementara itu, metode think pair share menurut (Hamdayama, 2014) merupakan suatu teknik sederhana dengan keuntungan besar. TPS dapat meningkatkan kemampuan siswa dalam mengingat suatu informasi dan seorang siswa juga dapat belajar dari siswa lain serta saling menyampaikan idenya untuk didiskusikan sebelum disampaikan di depan kelas. Hal ini juga senada dengan (Trianto, 2009) yang mengemukakan bahwa pembelajaran Think Pair Share (TPS) merupakan jenis pembelajaran kooperatif yang dirancang untuk memengaruhi pola interaksi siswa.

Dari paparan di atas dapat disimpulkan bahwa metode Think Pair Share (TPS) akan dapat meningkatkan keaktifan siswa di dalam kelas. Selain itu metode tersebut juga dapat menumbuhkan rasa percaya diri siswa, karena siswa akan berdiskusi dengan pasangannya (pair) untuk memecahkan masalah yang diberikan oleh guru. Siswa juga berbagi (share) kepada temanteman sekelasnya dengan mempresentasikan hasil diskusinya dengan pasangannya. Selain itu dengan penggunaan metode ini siswa akan lebih menguasai materi, karena siswa harus berpikir (think) untuk menyelesaikan masalah yang ditugaskan kepadanya. 


\section{METODE PENELITIAN}

Penelitian ini merupakan penelitian kuantitatif dengan menggunakan metode eksperimen. Desain penelitian yang digunakan adalah Pretest-Posttest Control Group Design. Dalam penelitian ini terdapat dua kelompok yaitu kelas eksperimen dan kelas kontrol. Kelas eksperimen diberikan perlakuan menggunakan model pembelajaran cooperative learning tipe Think Pair Share (TPS) dan pada kelas kontrol menggunakan pelajaran konvensional. Sebelum diberikan perlakuan, kedua kelompok kelas tersebut diberikan pretes terlebih dahulu, kemudian dilanjutkan dengan memberikan perlakuan yang berbeda pada masing-masing kelas yang telah ditentukan. Setelah diberikan perlakuan pada masing-masing kelas, selanjutnya dilakukan posttest untuk mendapatkan nilai hasil belajar akhir.

Populasi dalam penelitian ini adalah seluruh siswa-siswi MI Negeri Kota Cirebon yang berjumlah 290 Siswa. Sementara itu peneliti menggunakan teknik purposive sampling sebagai teknik pengambilan sampel. Purposive sampling adalah teknik pengumpulan sampel dengan pertimbangan tertentu (Sugiyono, 2015). Sehingga yang menjadi sampel dalam penelitian ini adalah siswa kelas $\mathrm{V}$ dengan jumlah 22 siswa.

Teknik pengumpulan data dalam penelitian ini yaitu (1) Tes. Tes ini berupa tes tulis yang dilakukan pada saat prettest dan posttest. Tes ini dilakukan untuk mengukur seberapa jauh pemahaman siswa terhadap materi qiro'ah dalam pelajaran bahasa Arab ketika sebelum dan sesudah pelajaran. Tes merupakan suatu tugas atau serangkaian tugas yang diberikan kepada individu atau sekelompok individu, dengan maksud untuk membandingkan kecakapan mereka, satu dengan yang lain (Sugiyono, 2015). (2) Angket atau Quesioner adalah teknik pengumpulan data yang dilakukan dengan cara memberi seperangkat pertanyaan atau pernyataan tertulis kepada responden untuk dijawabnya (Sugiyono, 2015). Angket ini bertujuan untuk mengetahui respon siswa terhadap penggunaan model pelajaran think pair share dalam proses pelajaran bahasa Arab. Bentuk instrumen ini menggunakan bentuk skala likert yang mana skala likert ini digunakan untuk jawaban yang bersifat jelas (Sangat Setuju, Setuju, Tidak Setuju, Sangat Tidak Setuju). (3) Dokumentasi merupakan teknik yang dilakukan terhadap data yang berbentuk dokumen-dokumen yang berhubungan dengan pembahasan dalam penelitian.

Selanjutnya, Teknik analisis data yang digunakan yakni analisis data angket, uji n-gain dan uji regresi. Dalam menganalisis data angket, peneliti menggunakan rumus prosentase angket sebagai berikut: $P=\frac{x}{A} x 100 \%$ (Riduwan, 2013). Sementara itu, uji $n$-gain digunakan untuk mengetahui seberapa besar peningkatan hasil belajar peserta didik pada kelas eksperimen 
berdasarkan nilai pretest dan posttest. Uji n-gain dapat dihitung menggunakan rumus Normalized Gain $\langle g\rangle$ berikut: $\langle g\rangle=\frac{\text { nilai postes }- \text { nilai pretes }}{\text { nilai maksimal }- \text { nilai pretes }} \times 100 \%$

Sedangkan analisis regresi digunakan untuk menelaah apakah variabel independen mampu mempengaruhi variabel dependen dalam suatu fenomena yang kompleks, dalam hal ini hasil belajar siswa pada materi qiro'ah di kelas V MI Negeri Kota Cirebon. Analisis Regresi menurut (Sugiyono, 2015) menggunakan rumus : $Y=a+b x$

\section{HASIL DAN PEMBAHASAN}

\section{A. Hasil Penelitian}

\section{Analisis Data Angket}

'Adapun hasil analisis data angket terhadap penggunaan model Cooperative Learning Tipe Think Pair Share di kelas V MI Negeri Kota Cirebon adalah sebagai berikut:

Grafik 1. Rekapitulasi Angket Positif

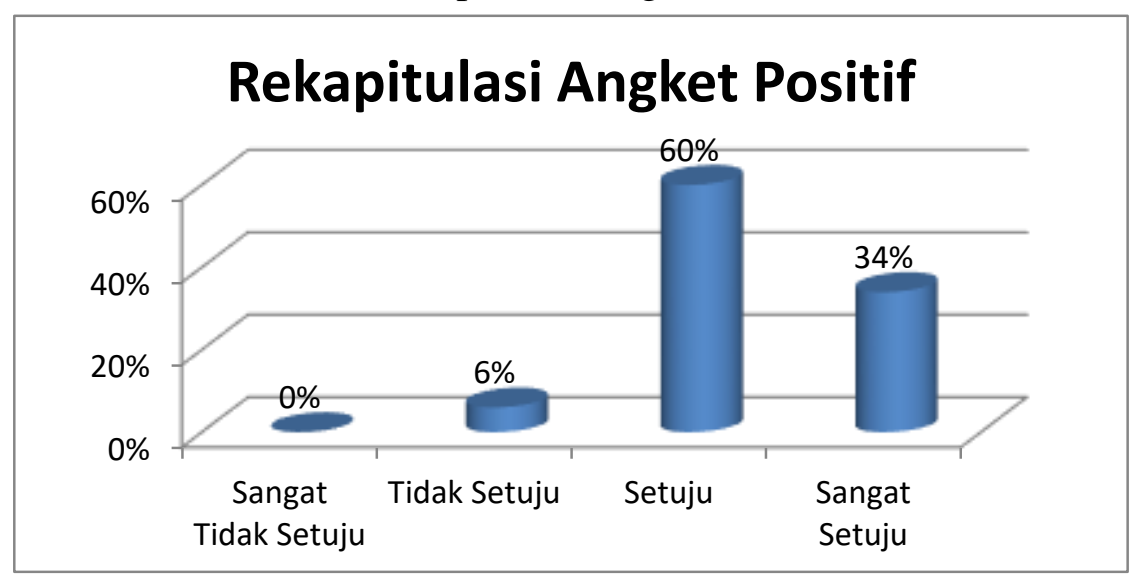

Dari hasil rekapitulasi angket positif pada grafik 1 menunjukkan bahwa rata-rata siswa menjawab setuju $60 \%$ dan sangat setuju 34\%. Ini berarti bahwa sebagian besar siswa merespon positif terhadap penggunaan model pembelajaran cooperative learning tipe think pair share pada pelajaran bahasa arab di kelas V MI Negeri Kota Cirebon.

Grafik 2. Rekapitulasi Angket Negatif

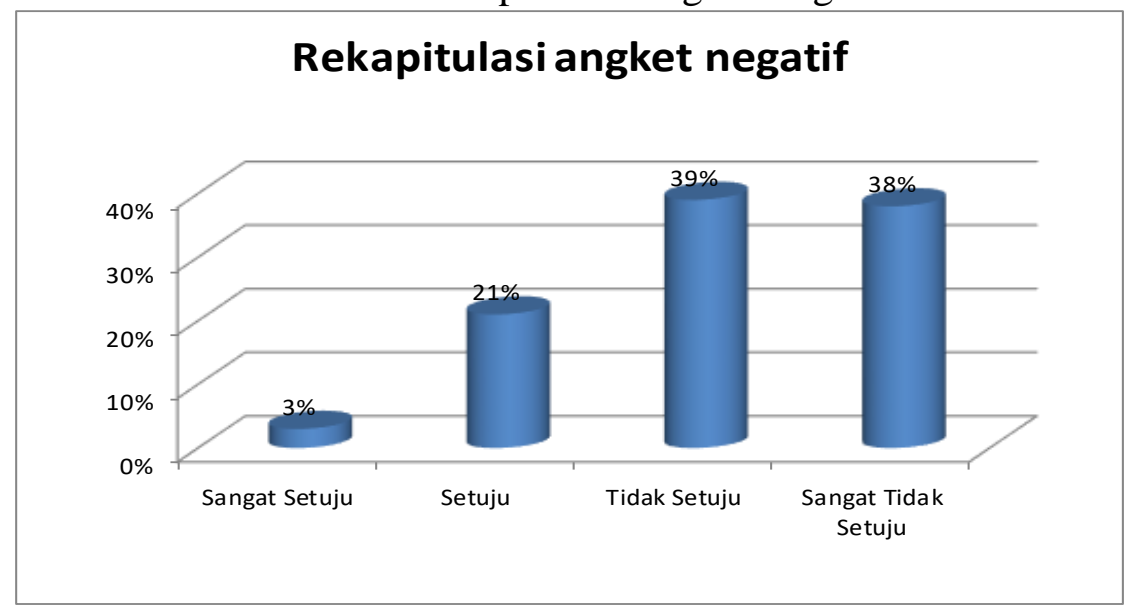


Dari hasil rekapitulasi angket negatif pada grafik 2 menunjukkan bahwa siswa yang menjawab setuju sebesar $21 \%$, yang menjawab tidak setuju sebesar $39 \%$ dan yang menjawab sangat tidak setuju sebesar 38\%. Ini berarti bahwa siswa yang merespon negative terhadap penggunaan model pembelajaran cooperative learning tipe think pair share pada pelajaran bahasa arab di kelas V MI Negeri Kota Cirebon hanya sebesar $24 \%$.

Berdasarkan uraian hasil rekapitulasi angket positif dan negatif di atas, untuk mengetahui kuat tidaknya hasil angket tersebut, maka peneliti melakukan analisis terhadap angket tersebut dengan menggunakan raing scale. Adapun rating scale data angket tersebut adalah sebagai berikut:

Tabel 1. Rating Scale Rekapitulasi Data Angket

\begin{tabular}{|c|c|c|c|c|c|c|c|c|c|c|}
\hline \multirow{2}{*}{ No } & \multicolumn{2}{|l|}{1} & \multicolumn{2}{|l|}{2} & \multicolumn{2}{|l|}{3} & \multicolumn{2}{|l|}{4} & \multicolumn{2}{|c|}{ JUMLAH } \\
\hline & $\mathrm{F}$ & $\mathrm{P}$ & $\mathrm{F}$ & $\mathrm{P}$ & $\mathrm{F}$ & $\mathrm{P}$ & $\mathrm{F}$ & $\mathrm{P}$ & $\mathrm{F}$ & $\mathrm{P}$ \\
\hline 1 & 2 & 3 & 4 & 5 & 6 & 7 & 8 & 9 & 10 & 11 \\
\hline 1 & 0 & 0 & 0 & 0 & 8 & 24 & 14 & 56 & 22 & 80 \\
\hline 2 & 3 & 3 & 1 & 2 & 9 & 27 & 9 & 36 & 22 & 68 \\
\hline 3 & 0 & 0 & 0 & 0 & 9 & 27 & 13 & 52 & 22 & 79 \\
\hline 4 & 0 & 0 & 4 & 8 & 13 & 39 & 5 & 20 & 22 & 67 \\
\hline 5 & 0 & 0 & 0 & 0 & 14 & 42 & 8 & 32 & 22 & 74 \\
\hline 6 & 0 & 0 & 3 & 6 & 15 & 45 & 4 & 16 & 22 & 67 \\
\hline 7 & 0 & 0 & 5 & 10 & 11 & 33 & 6 & 24 & 22 & 67 \\
\hline 8 & 1 & 1 & 4 & 8 & 6 & 18 & 11 & 44 & 22 & 71 \\
\hline 9 & 0 & 0 & 7 & 14 & 7 & 21 & 8 & 32 & 22 & 67 \\
\hline 10 & 1 & 1 & 10 & 20 & 0 & 0 & 11 & 44 & 22 & 65 \\
\hline 11 & 0 & 0 & 4 & 8 & 10 & 30 & 8 & 32 & 22 & 70 \\
\hline 12 & 0 & 0 & 2 & 4 & 17 & 51 & 3 & 12 & 22 & 67 \\
\hline 13 & 0 & 0 & 0 & 0 & 12 & 36 & 10 & 40 & 22 & 76 \\
\hline 14 & 0 & 0 & 2 & 4 & 15 & 45 & 5 & 20 & 22 & 69 \\
\hline 15 & 0 & 0 & 0 & 0 & 21 & 63 & 1 & 4 & 22 & 67 \\
\hline 16 & 0 & 0 & 0 & 0 & 14 & 42 & 8 & 32 & 22 & 74 \\
\hline 17 & 0 & 0 & 4 & 8 & 11 & 33 & 7 & 28 & 22 & 69 \\
\hline 18 & 0 & 0 & 0 & 0 & 12 & 36 & 10 & 40 & 22 & 76 \\
\hline 19 & 0 & 0 & 2 & 4 & 12 & 36 & 8 & 32 & 22 & 72 \\
\hline 20 & 0 & 0 & 4 & 8 & 10 & 30 & 8 & 32 & 22 & 70 \\
\hline JML & 5 & 5 & 52 & 104 & 226 & 678 & 157 & 628 & 440 & 1415 \\
\hline
\end{tabular}

Keterangan:

$\mathrm{F}=$ Frekuensi $\mathrm{P}=$ Prosentase

Berdasarkaan data yang diperoleh dari 22 responden dengan jumlah item angket sebanyak 20, maka skor ideal untuk variable kreativitas guru tersebut adalah 20 item x 22 responden $\mathrm{x} 4$ (skor tertinggi tiap item $)=1760$. Jumlah pencapaian skor hasil penyebaran angket adalah 1415. Maka presentase pencapaian skor respon siswa adalah:

$$
\frac{1415}{1760} \times 100 \%=80,4 \%
$$

Skor tersebut tergolong pada kategori sangat kuat yang berada di antara $80 \%-100 \%$. 


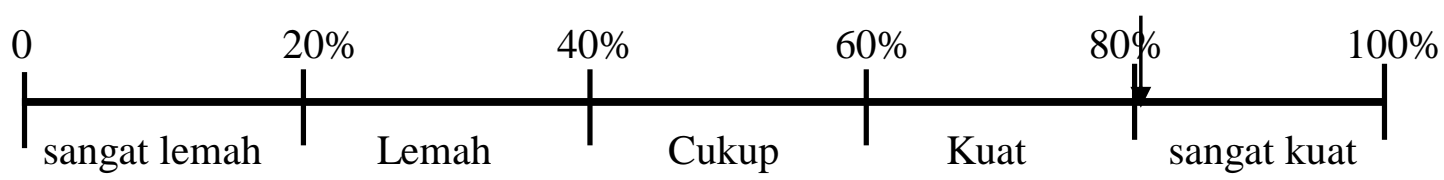

\section{Analisis Data Tes}

Untuk mengetahui hasil belajar siswa kelas eksperimen dan kelas kontrol pada mata pelajaran bahasa Arab materi qiro'ah di kelas V MI Negeri Kota Cirebon, dapat dilakukan dengan melakukan analisis uji n-gain. Adapun hasil rekapitulasi data kelas eksperimen dan kelas kontrol adalah sebagai berikut :

Tabel 2. Rekapitulasi Uji N-Gain Kelas Eksperimen dan Kelas Kontrol

\begin{tabular}{|c|c|c|c|c|c|c|c|c|}
\hline \multirow[b]{3}{*}{ kelas } & \multicolumn{6}{|c|}{ Kriteria Indeks Gain Tiap Siswa } & \multirow{3}{*}{$\begin{array}{l}\text { Hasil } \\
\text { Rataan } \\
\text { Indeks } \\
\text { Gain }\end{array}$} & \multirow{3}{*}{$\begin{array}{l}\text { Kriteria } \\
\text { Indeks } \\
\text { Gain }\end{array}$} \\
\hline & \multicolumn{2}{|c|}{ Rendah } & \multicolumn{2}{|c|}{ Sedang } & \multicolumn{2}{|c|}{ Tinggi } & & \\
\hline & $\mathrm{F}$ & Persen & $\mathrm{F}$ & Persen & $\mathrm{F}$ & Persen & & \\
\hline Eksperimen & 0 & $0 \%$ & 17 & $77 \%$ & 5 & $23 \%$ & 0.588 & Sedang \\
\hline Kontrol & 6 & $27 \%$ & 16 & $73 \%$ & 0 & $0 \%$ & 0.391 & Sedang \\
\hline
\end{tabular}

Berdasarkan tabel 2 diperoleh bahwa hasil analisis uji n-gain pada kelas eksperimen menunjukkan kategori sedang yaitu sebanyak 17 siswa (77\%) dan yang termasuk dalam kategori tinggi sebanyak 5 siswa (23\%). Peningkatan rata-rata uji n-gain dari pretes ke postes adalah sebesar 0,588 dengan kategori sedang.

Sementara itu hasil uji n-gain pada kelas kontrol menunjukkan kategori rendah sebanyak 6 siswa (27\%), dan jumlah siswa yang termasuk ke dalam kategori sedang yaitu sebanyak 16 siswa (73\%) serta tidak ada siswa yang termasuk dalam kategori tinggi. Peningkatan rata-rata hasil uji n-gain dari pretes ke postes adalah sebesar 0,391 dengan kategori sedang.

Untuk dapat melihat hasil pretest dan posttest pada kelas Eksperimen mata pelajaran bahasa Arab materi qiro'ah di kelas V MI Negeri Kota Cirebon, dapat dilihat pada tabel 3 berikut:

Tabel 3. Hasil Pretest dan Posttest Kelas Eksperimen

\begin{tabular}{llllll}
\hline NO & Siswa & Pretes & Postes & Gain & Kriteria \\
\hline 1 & Siswa 1 & 59 & 82 & 0,556 & Sedang \\
\hline 2 & Siswa 2 & 36 & 73 & 0,571 & Sedang \\
\hline 3 & Siswa 3 & 50 & 91 & 0,818 & Tinggi \\
\hline 4 & Siswa 4 & 41 & 77 & 0,615 & Sedang \\
\hline 5 & Siswa 5 & 50 & 77 & 0,545 & Sedang \\
\hline 6 & Siswa 6 & 55 & 86 & 0,700 & Tinggi \\
\hline 7 & Siswa 7 & 41 & 73 & 0,538 & Sedang \\
\hline
\end{tabular}




\begin{tabular}{|c|c|c|c|c|c|}
\hline 8 & Siswa 8 & 32 & 73 & 0,600 & Sedang \\
\hline 9 & Siswa 9 & 50 & 86 & 0,727 & Tinggi \\
\hline 10 & Siswa 10 & 45 & 73 & 0,500 & Sedang \\
\hline 11 & Siswa 11 & 55 & 73 & 0,400 & Sedang \\
\hline 12 & Siswa 12 & 45 & 77 & 0,583 & Sedang \\
\hline 13 & Siswa 13 & 45 & 82 & 0,667 & Sedang \\
\hline 14 & Siswa 14 & 41 & 77 & 0,615 & Sedang \\
\hline 15 & Siswa 15 & 41 & 73 & 0,538 & Sedang \\
\hline 16 & Siswa 16 & 59 & 73 & 0,333 & Sedang \\
\hline 17 & Siswa 17 & 45 & 73 & 0,500 & Sedang \\
\hline 18 & Siswa 18 & 32 & 82 & 0,733 & Tinggi \\
\hline 19 & Siswa 19 & 45 & 73 & 0,500 & Sedang \\
\hline 20 & Siswa 20 & 41 & 73 & 0,538 & Sedang \\
\hline 21 & Siswa 21 & 55 & 100 & 1,000 & Tinggi \\
\hline & Siswa 22 & 50 & 68 & 0,364 & Sedang \\
\hline \multicolumn{2}{|c|}{ Total } & 1014 & 1714 & 13 & \\
\hline \multicolumn{2}{|c|}{ Rata-rata } & 46 & 78 & 0,588 & Sedang \\
\hline
\end{tabular}

Berdasarkan tabel 3 menunjukkan bahwa nilai rata-rata pretest sebesar 46 sedangkan nilai rata-rata posttest sebesar 78, sehingga terjadi peningkatan yang signifikan antara nilai pretes dan nilai postes.

\section{Analisis Uji Hipotesis}

\section{a. Uji Determinasi (R Square)}

Untuk mengetahui pengaruh penggunaan model cooperative learning tipe think pair share terhadap hasil belajar siswa maka dilakukan uji determinasi (R Square). Adapun hasil uji determinasinya adalah sebagai berikut :

Tabel 4. Uji Determinasi

\begin{tabular}{lccccr}
\hline \multicolumn{5}{c}{ Model Summary } \\
\hline Todel & R & R Square & $\begin{array}{l}\text { Adjusted } \\
\text { Square }\end{array}$ & $\begin{array}{l}\text { R Std. Error } \\
\text { Estimate }\end{array}$ & of the \\
\hline 1 & $.707^{\text {a }}$ & .500 & .475 & 5.44027 \\
\hline a. Predictors: (Constant), model Cooperative Learning tipe Think-Pair- \\
Share (TPS)
\end{tabular}

Pada tabel 4 di atas terdapat $R$ Square sebesar 0,500 (kuadrat dari koefisien korelasi 0,707). $R$ Square disebut koefisien determinan yang dalam hal ini sebesar $50 \%$. Dari nilai tersebut dapat diartikan bahwa penggunaan model Cooperative Learning tipe Think-Pair-Share (TPS) berpengaruh sebesar 50\% terhadap hasil belajar bahasa Arab materi Qiroah di Kelas V MI Negeri Kota Cirebon, sedangkan sisanya dipengaruhi oleh faktor lain. 
b. Uji Regresi

Analisis uji regresi digunakan untuk mengetahui pengaruh antara variabel bebas dengan variabel terikat yang ditampilkan dalam bentuk persamaan regresi. Berikut hasil analisisnya :

Tabel 5. Uji Regresi

\begin{tabular}{|c|c|c|c|c|c|c|}
\hline \multicolumn{7}{|c|}{ Coefficients $^{\mathrm{a}}$} \\
\hline \multirow{2}{*}{\multicolumn{2}{|c|}{ Model }} & \multicolumn{2}{|c|}{$\begin{array}{l}\text { Unstandardized } \\
\text { Coefficients }\end{array}$} & \multirow{2}{*}{$\begin{array}{l}\text { Standardized } \\
\text { Coefficients } \\
\text { Beta }\end{array}$} & \multirow[t]{2}{*}{$\mathrm{t}$} & \multirow[t]{2}{*}{ Sig. } \\
\hline & & $\mathrm{B}$ & $\begin{array}{l}\text { Std. } \\
\text { Error }\end{array}$ & & & \\
\hline \multirow{6}{*}{1} & (Constant) & -5.533 & 18.719 & & -.296 & .771 \\
\hline & model & 1.298 & .290 & .707 & 4.469 & .000 \\
\hline & Cooperative & & & & & \\
\hline & Learning tipe & & & & & \\
\hline & Think-Pair-Share & & & & & \\
\hline & (TPS) & & & & & \\
\hline \multicolumn{7}{|c|}{ a. Dependent Variable: hasil belajar siswa } \\
\hline
\end{tabular}

$\mathrm{Y}$ adalah variabel dependent, dalam hal ini adalah Hasil Belajar, dan $\mathrm{X}$ adalah variabel independent, dalam hal ini adalah model Cooperative Learning tipe Think Pair Share (TPS). Sedangkan a dan b adalah nilai konstanta yang dicari.

Berdasarkan hasil regrasi diketahui nilai constant-nya adalah $-5,533$ dan nilai Hasil Belajar adalah 1,298. Dari keterangan tersebut kita dapat memperoleh persamaan regresi sebagai berikut:

$$
\mathbf{Y}=-5,533+1,298 \mathbf{X}
$$

Nilai konstanta dari koefficien regresi sebesar $-5,533$, hal ini menyatakan bahwa jika tidak ada kenaikan nilai atau skor dari variabel Model Cooperative Learning tipe Think Pair Share (TPS), maka variabel hasil belajar adalah-5,533. Koefficien regresi sebesar 1,298 menyatakan bahwa setiap terjadi penambahan skor variabel model Cooperative Learning tipe Think Pair Share (TPS) akan dapat menambah kenaikan variabel Hasil Belajar.

Setelah mengetahui besarnya koefisien regresi, maka perlu dilakukan pengujian hipotesis untuk mengetahui apakah pengaruhnya signifikan atau tidak. Berdasarkan hasil uji regresi di atas nilai signifikansinya sebesar 0,000. Karena nilai signifikan lebih kecil dari 0,05 dan t hitung (4.469) lebih besar dari t tabel (2.09302) maka Ho ditolak, artinya bahwa penggunaan model Cooperative Learning tipe Think-PairShare (TPS) berpengaruh signifikan terhadap hasil belajar siswa mata pelajaran bahasa Arab materi Qiroah di Kelas V MI Negeri Kota Cirebon. 


\section{B. Pembahasan}

1. Penggunaan Model Cooperative Learning Tipe Think Pair Share (TPS) Pada Pelajaran Bahasa Arab Materi Qiro'ah di Kelas V MI Negeri Kota Cirebon.

Berdasarkan hasil penelitian yang telah dilakukan oleh peneliti dengan menggunakan model cooperative learning tipe think pair share pada pelajaran bahasa Arab materi qiro'ah diperoleh bahwa dari 22 responden, 18 responden merespon positif terhadap penggunaan model cooperative learning tipe think pair share pada pelajaran bahasa Arab materi qiro'ah. Jumlah ini diperoleh dari jumlah item angket sebanyak 20, maka skor ideal untuk respon siswa tersebut adalah 20 item x 22 responden x 4 (skor tertinggi tiap item $)=1760$. Jumlah pencapaian skor hasil penyebaran angket adalah 1415 . Maka presentase pencapaian skor respon siswa adalah:

\section{$\frac{1415}{1760} \times 100 \%=80,4 \%$}

Skor tersebut tergolong pada kategori sangat kuat yang berada di antara $80 \%-100 \%$.

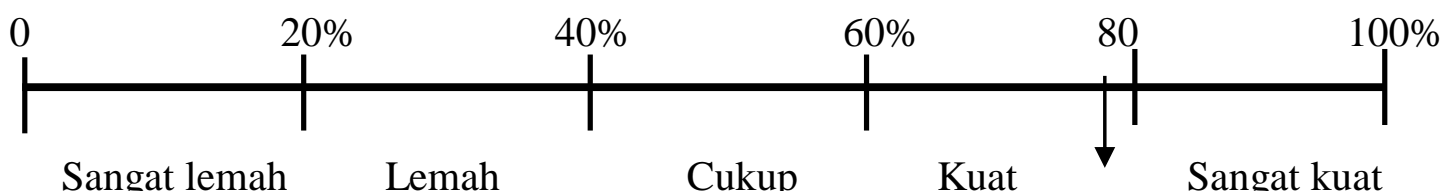

Jadi dapat disimpulkan bahwa respon siswa terhadap penggunaan model cooperative learning tipe think pair share pada pelajaran bahasa Arab materi qiro'ah sangat kuat, yakni $80,4 \%$. Kuatnya respon siswa terhadap penggunaan model cooperative learning tipe think pair share ini karena memang metode ini memberikan kesempatan kepada siswa lebih banyak waktu untuk berpikir, baik secara individu maupun berpasangan sehingga dapat saling merespon dan saling membantu dalam memahami materi yang sedang dipelajarinya (Zulkarnain dan Djamilah, 2015). Di samping itu siswa juga akan mengembangkan kemampuan untuk menguji ide dan pemahamannya sekaligus membandingkan dengan ide yang dikemukakan oleh siswa lain sehingga dapat terjadi interaksi diantara anggota pasangan tersebut.

\section{Hasil Belajar Siswa Pada Pelajaran Bahasa Arab Materi Qiro'ah dengan} Menggunakan Model Cooperative Learning Tipe Think Pair Share (TPS) Di Kelas V MI Negeri Kota Cirebon.

Berdasarkan hasil penelitian yang telah dipaparkan menunjukkan bahwa hasil belajar siswa kelas V MI Negeri Kota Cirebon yang berjumlah 22 siswa mengalami peningkatan yang signifikan. Hal ini dapat dilihat dari nilai rata-rata pretes sebesar 46 dan nilai rata-rata postes sebesar 78. Berdasarkan hasil analisis uji n-gain pada kelas eksperimen juga menunjukkan kategori sedang yaitu sebanyak 17 siswa (77\%) dan yang 
termasuk dalam kategori tinggi sebanyak 5 siswa (23\%). Peningkatan rata-rata uji n-gain dari pretes ke postes adalah sebesar 0,588 dengan kategori sedang. Hal ini juga sejalan dengan hasil penelitian yang dilakukan oleh (Dewi, 2015), (Kusumastuti \& Susilo, 2013), (Indahsari, Widihastrini, \& Sulistiyorini, 2013) yang mengungkapkan bahwa penggunaan model cooperative learning tipe think pair share mampu meningkatkan hasil belajar siswa.

\section{Pengaruh Penggunaan Model Cooperative Learning Tipe Think Pair Share (TPS) Pada Pelajaran Bahasa Arab Materi Qiro'ah di Kelas V MI Negeri Kota Cirebon.}

Pengaruh penggunaan model pembelajaran cooperative learning tipe think pair share (TPS) terhadap hasil belajar siswa dapat dilihat dari hasil analisis uji regresi. Berdasarkan hasil uji regresi diperoleh bahwa nilai R Square sebesar 0,500 (kuadrat dari koefisien korelasi 0,707). R Square disebut koefisien determinan yang dalam hal ini sebesar 50\%. Dari nilai tersebut dapat diartikan bahwa 50\% pengaruh penggunaan model Cooperative Learning tipe think pair share pada mata pelajaran bahasa Arab materi Qiro'ah di Kelas V MI Negeri Kota Cirebon sedangkan sisanya dipengaruhi oleh faktor lain.

Berdasarkan hasil uji regresi di atas nilai signifikansinya sebesar 0,000. Karena nilai signifikansinya lebih kecil dari 0,05 dan t hitung (4.469) lebih besar dari t tabel (2.09302) maka Ho ditolak, artinya bahwa penggunaan model Cooperative Learning tipe think pair share berpengaruh signifikan terhadap hasil belajar siswa mata pelajaran bahasa Arab materi Qiroah di Kelas V MI Negeri Kota Cirebon.

Penggunaan model Cooperative Learning tipe Think Pair Share (TPS) dapat membuat siswa menjadi lebih aktif, dan tidak hanya bertambah pengetahuan atau peningkatan prestasinya saja, tetapi juga komunikasi interaksi sosial dan kerja sama antar siswa pun akan tercipta dan meningkat dalam usaha peencapaian tujuan belajar.

\section{SIMPULAN}

Berdasarkan uraian hasil penelitian di atas, dapat disimpulkan sebagai berikut:

1. Respon siswa terhadap penggunaan model Cooperative Learning tipe Think Pair Share pada pelajaran bahasa arab materi qiro'ah di kelas V MI Negeri Kota Cirebon menunjukkan respon positif yang sangat kuat yaitu mencapai $80,4 \%$.

2. Hasil belajar siswa pada pelajaran bahasa Arab materi qiro'ah dengan menggunakan model Cooperative Learning tipe Think Pair Share pada kelas eksperimen mengalami peningkatan yang signifikan antara nilai pretes dan nilai postes, yakni sebesar 0,588 dengan kategori sedang. 
3. Penggunaan model Cooperative Learning tipe Think Pair Share (TPS) berpengaruh terhadap hasil belajar siswa pada pelajaran bahasa arab materi qiro'ah_di kelas V MI Negeri Kota Cirebon. Besarnya pengaruh sebesar 50\% dan sisanya dipengaruhi oleh faktor lain.

\section{DAFTAR PUSTAKA}

Akhyak. (2005). Profil Pendidik Sukses. Surabaya: eLKAF.

Azizah, N. L. (2010). Penerapan Pelajaran Kooperatif Metode Think-Pair-Share (TPS) untuk Meningkatkan Kemampuan Berbicara Bahasa Arab Siswi Kelas VII MTs. Skripsi: Jurusan Sastra Arab, Universitas Negeri Malang.

Dewi, C. (2015). Penerapan Model Pelajaran Kooperatif Tipe Think Pair Share untuk Meningkatkan Pemahaman Konsep Masalah Sosial IPS pada Siswa Sekolah Dasar. Premiere Educandum, 5(2), 155-167.

Hamdayama, J. (2014). Model dan Metode Pelajaran Kreatif dan Berkarakter. Bogor: Ghalia Indonesia.

Indahsari, D. N., Widihastrini, F., \& Sulistiyorini, S. (2013). Peningkatan Kualitas Pelajaran IPA melalui Model TPS Berbantuan Macromedia Flash. Joyful Learning Journal, 2(3), 47-54.

Kusumastuti, A., \& Susilo, K. (2013). Peningkatan Kualitas Pelajaran IPS Melalui Model Think Pair Share Berbantuan Video Pelajaran pada Siswa Kelas V A SDN Bojong Salaman 02 Kota Semarang. Joyful Learning Journal, 2(3), 63-69.

Masrifah, Z. (2010). Penerapan Pelajaran Kooperatif Model Think-Pair-Share (TPS) untuk Meningkatkan Prestasi Belajar pada Keterampilan Membaca Bahasa Arab di MTsN 2 Malang. Skripsi: Jurusan Sastra Arab, Universitas Negeri Malang.

Muharamsyah, D., Hardhienata, S., \& Entang, M. (2016). Penerapan Model Student Teams Achievement Divisions (STAD) dan Think Pair Share (TPS) untuk Meningkatkan Keterampilan Berbicara dan Menulis Bahasa Arab pada Siswa Kelas X SMA Terpadu Al Ma'shum Mardiyah Cianjur. Jurnal Manajemen Pendidikan, 4(1), 27-37.

Riduwan. (2013). Dasar-dasar Statistika. Bandung: Alfabeta.

Slavin, R. (2008). Cooperative Learning Teori Riset dan Praktik. diterjemahkan oleh Nurlita. Bandung: Nusa.

Sugiyono. (2015). Metode Penelitian Pendidikan . Bandung : Alfabeta.

Sumantri, M. (2015). Strategi Pelajaran. Jakarta: Rajawali Pers.

Trianto. (2009). Mendesain Model Pelajaran Inovatif-Progresif. Jakarta: Kencana Prenada Media Group. 